\title{
Citizenship and Human Rights Within the Scope of Values Education
}

\author{
Mehmet Fatih Yigit ${ }^{1}$ \\ Independent Researcher, Turkey
}

\begin{abstract}
Using a social studies course with an interdisciplinary approach and organizing the program in conjunction with this circumstance means that the social studies curriculum can find its place in the real world because interdisciplinary nature enhances its value. The definition of the National Council on Social Studies in the United States in 1992 is also important in emphasizing how comprehensive this course is. According to this definition, social studies collaborate with different sciences such as anthropology, archeology, history, geography, law, economics, philosophy, political science, religion, psychology, and sociology. In addition to citizenship rights and responsibilities, the topics that include human rights, in general, are covered in the social studies course. In this light, social studies can be viewed as a course in which citizenship rights and obligations are taught to raise individuals who are responsive to human rights. In this context, the four main values, feeling valuable, equality, democratic education, and a culture of coexistence, that can be offered within the framework of citizenship and human rights in social studies courses are discussed below.
\end{abstract}

Keywords: citizenship, democratic education, human rights education, social studies, values education.

\section{People are Valuable}

Social and global justice is easier to achieve in a world where human beings are treated as individuals, and their rights are respected accordingly. To value a person not as superior or inferior to others because of his color, language, or race is to value him/her as a human being. The value of people must be instilled in children at an early age in educational institutions. Individual and social harmony can be achieved by raising awareness of the importance of human beings in the face of social and individual developments among those who have progressed from primary education to secondary education and then to higher education (Yigit, 2018). Indeed, it would not be incorrect to claim that human nature has good and bad qualities from birth that are later channeled for better or worse by the world where the person lives and the education he/she receives. One of the main objectives of education is to reveal valuable and positive aspects in human beings (Ergün, 1993). The National Education Association in 1938 proclaimed that the safety of democracy will not be ensured just by universalizing education. The task isn't as simple as that. The dictatorships have universal education and use it to keep democratic ideologies and institutions from spreading. Schools had to explicitly concentrate on teaching democratic principles and behaviors, which can not be expected by simply reading and math proficiency (Rothstein \& Jacobsen, 2006).

Social studies has the potential to teach students that people should be valued for being human beings and need to be carefully considered. Unfortunately, these two lessons are often

${ }^{1}$ Corresponding Author E-Mail: fatihyigit6@gmail.com 
ignored and not given the necessary attention. Paying attention to the preparation of teachers who will provide these courses to address the situation is important. The presence of teachers who believe that social studies or civics and democracy education courses are effective in creating a healthy society will naturally mean younger generations who are raised in line with the same consciousness (Arslan \& Yigit, 2016). In this sense, teachers expected to;

- Be role models;

- Create a common social texture in the classroom environment;

- Be responsible to each student and contribute to their development;

- Encourage students to learn values;

- Allow students to make decisions;

- Encourage students to work together; and

- Create discussion environments (Tyree, 1997)

Values and social studies education play a critical role in instilling in future generations that human beings are equal and all people should be treated following this idea. To say that a person is important implies that he/she should be valued for all of the qualities that he possesses. In this respect, primary school students must effectively learn tolerance in a society containing different cultures (Yiğit \& Kesmeci, 2015).

It is natural to have certain expectations from a morally developed and mature individual. Social studies and citizenship and democracy course also play a key role in raising individuals who can meet these expectations. What these expectations are is a matter of debate. It has been constantly discussed whether the values to be taught in school are the family, authority, or other sources (Bailey, 2000). However, in general, the expected values can be summarized as below (Martorella, 1998).

\section{a) All individuals' values and rights must be respected}

The main thing to remember here is that people do not believe they have unrestricted rights. The expression "one's freedom ends where someone else's freedom starts" is frequently explained as a general rule in democratic societies but sadly does not occur when applied most of the time. Because social studies are more of a course taken by students who are in the period of both moral, physical, and spiritual development, it will be easier for these views to mature and gain acceptance when students are given the awareness that the values and rights of others should be respected (Pieper \& Thomson, 2014). Cultural and value differences is not only to be respected in educational environments. They are also important to get realized in all areas of life. As an example, management area is one of those where respecting core human values and local traditions are important for managers establish codes of conduct for globally ethical business practice (Donaldson, 2016). On the other hand, establishing a consciousness about human rights and values might sometimes be difficult especially in so-called democratic societies (Ogurlu \& Avincan, 2020). Human rights theories inherently grant rights to all humankind universally however (Jones, 2018), granting it philosophically might make a difference compared to the situations where the rights are granted politically. 


\section{b) Avoid fraud}

One of the most common practices in all cultures that we might term a "common crime" is defrauding or deceiving others in various ways. In societies where such despicable crimes are committed, from the smallest unit to the largest one, all segments of society are negatively affected, and unpleasant situations arise. It is important to instill in individuals who are still in the developmental stage that preventing fraud is a general moral value. In this regard, educational institutions play an important role. It is essential for teachers to play a positive role in this sense, show sample scenarios showing how fraud or similar ordinary crimes are met in society, and ensure that this is also included in family and environmental life. When we realize that people who commit such minor crimes are usually excluded from society, believe that they are useless, and have no purpose, the value of increasing public awareness becomes much greater (Amin \& Ahmad, 2018). It should not be forgotten that in a society where the individual feels valuable, such ordinary crimes will not be committed or will be minimized.

\section{c) To achieve equality between individuals}

In the classroom environment, when teachers or administrators in the school discriminate between students and place one above the others, the moral development of the students will be negatively affected. Teachers who treat students equally and give them an equal voice, especially in the classroom, will positively impact students' social lives (Cin, 2017). In one study, primary school students were asked about the characteristics of an effective teacher. The children stated that an effective teacher should love children very much, be patient and tolerant and treat everyone equally (Gökçe, 2002). Another research stated that three characteristics of effective teachers were nonverbal communication, teacher self-efficacy, and servant leadership (Steele, 2010).

\section{d) Working together with people of different opinions}

Recognizing people's freedom and ideas and working together with people of different opinions is of great importance for achieving the peace of mind needed in multicultural societies. Individuals who cannot get along with each other in social life, cannot tolerate different opinions, and cannot even accept the existence of people with different characteristics, constitute the segments that cause unrest in the society to develop and grow (Banban, 2018; Yigit, 2017). How we can gain the ability to coexist with people of different backgrounds and views and do the same job together will lead us to question the content of education given in primary school. The presence of students from diverse backgrounds in educational institutions is very common due to different cultural structures. The most basic way to teach students from different cultures and social structures in the classroom to tolerate each other, get into the habit of working together and respect opposing views is through teachers with a strong background in this field (Tonbuloğlu et al., 2016). Teachers, especially in social studies and citizenship and democracy education courses, will have a positive effect on these students who will be involved in social life in the following periods if they allow the students to work together in the same group and to ensure that opposite views come together in the same group. Students at this age will make positive contributions to social life and economically over time. It is important for countries that are part of the global economy to compete with the world and to cooperate with the business world of different nations. It is necessary to gain the ability to work with people of different opinions in primary school age. Social studies courses 
are essential in terms of having the potential to gain the ability to work together with people of different cultures, nationalities, religions, or races (Clark \& Hooser, 2018).

\section{e) Get rid of prejudices}

To know that everyone is valuable and embrace them, we must first get rid of our prejudices. Our relationships with people will be healthier if we think that human beings are inclined to make mistakes, but that making mistakes is the result of being human and knowing that a righteous person is the one who can turn away from his mistake and act accordingly. In the opposite case, assuming that a person should not make mistakes, that a wrongdoer should not be forgiven, or that the wrongdoer should be regarded with this mistake as a reference throughout his life suggests that we are looking for perfect people in society, which is unlikely. First of all, letting individuals look at their inner world is enough to eliminate such thoughts. Knowing that no individual is truly perfect is an important step towards getting rid of prejudices. In social studies or citizenship and democracy lessons, it is of great importance for teachers to instill the idea that 'there cannot be a faultless person' to students with the help of case studies or the idea that a person should not be treated with prejudice due to the cultural structure to which he or she is born (Salter et al., 2017) because they do not have the chance to choose from which cultural and social structure to belong to.

\section{Everyone Is Equal}

The Universal Declaration of Human Rights adopted and published by the United Nations General Assembly on 10 December 1948 has many provisions concerning equality. All articles are related to equality, but here we will directly mention the articles with the word equality.

Article 1: All human beings are born free and equal in dignity and rights. They are endowed with reason and conscience and should act towards one another in a spirit of brotherhood.

Article 7: All are equal before the law and are entitled without any discrimination to equal protection of the law. All are entitled to equal protection against any discrimination in violation of this Declaration and against any incitement to such discrimination.

Article 21: (1) Everyone has the right to take part in the government of his country, directly or through freely chosen representatives.

(2) Everyone has the right of equal access to public service in his country.

(3) The will of the people shall be the basis of the authority of government; this will shall be expressed in periodic and genuine elections which shall be by universal and equal suffrage and shall be held by secret vote or by equivalent free voting procedures.

Article 23: (1) Everyone has the right to work, to free choice of employment, to just and favorable conditions of work, and to protection against unemployment. 
(2) Everyone, without any discrimination, has the right to equal pay for equal work.

(3) Everyone who works has the right to just and favorable remuneration ensuring for himself and his family an existence worthy of human dignity, and supplemented, if necessary, by other means of social protection.

(4) Everyone has the right to form and to join trade unions for the protection of his interests.

Article 26: (1) Everyone has the right to education. Education shall be free, at least in the elementary and fundamental stages. Elementary education shall be compulsory. Technical and professional education shall be made generally available and higher education shall be equally accessible to all on the basis of merit.

(2) Education shall be directed to the full development of the human personality and to the strengthening of respect for human rights and fundamental freedoms. It shall promote understanding, tolerance, and friendship among all nations, racial or religious groups, and shall further the activities of the United Nations for the maintenance of peace.

(3) Parents have a prior right to choose the kind of education that shall be given to their children. (United Nations, 1948)

As can be seen in the above articles, the Universal Declaration of Human Rights emphasized that all human beings are equal and stated that this equality is present in all areas of life. There are rights that no one can be deprived of, especially based on citizenship (Owen, 2018).

People do not have the option of choosing their ethnicity, skin color, or family background. It is normal in societies, where democracy and a culture of respect for people are not established, to regard one as superior to the other. The role of social studies, civics, and democracy education courses in raising this consciousness cannot be ignored. The social studies course, which focuses on social issues and real-world issues, can play an important role in adopting the principle of equality in society. Working on exemplary circumstances in classrooms where students from various cultural, economic, and social backgrounds are participating will allow the problem to have a more tangible place in the minds of children. In these cases, as in all others, the instructor bears a great responsibility. Teachers who act following the principle of equality will indirectly increase the awareness of 'that should be treated this way' on children (Fine-Davis \& Faas, 2014). A teacher who treats all students fairly would significantly affect students' understanding of the importance of not discriminating in public. This, in turn, would raise public consciousness of democracy (Abdi \& Carr, 2012).

\section{Democratic Education}

In general, education is the process of creating a permanent traced behavioral change in the individual through his/her own life. It is an expression of raising people for specific purposes. Unlike the concept of teaching, it can also be viewed as improving the social processes of individuals in a broad sense. Here, the perspective of education is evaluated within the framework of democracy and the education relationship.

Democracy simply means "law of the people." The word is derived from the Greek dmokratia, which was coined in the middle of the 5th century BCE from dmos ("people") and 
kratos ("rule") to describe the political structures that existed in some Greek city-states, most notably Athens (Dahl, 2021). Based on today's living conditions and perspectives, democratic education is a form of education offered to the public and considers elements that aim to improve society and adapt to the information age (Sant, 2019).

Education is often shaped according to the life in which societies live. For example, in industrial societies, education is organized in parallel with production technology. In societies that can catch up and keep up with the information age, improvements have been made in education to raise the standards of people. In this context, the management styles, belief dimensions, and economic lives of societies are also very effective in education. When considered at the international point, the education systems of each country are different as well as the elements mentioned above.

Globalization and transformation also resulted in educational system innovations. While democracy makes the people have a say, democratic education also takes the interests and needs of the students into account (Patel, 2018). It makes them have the same say within the framework of the concept of equality. The teacher is no longer the narrator but a co-learner with students. The concept of class in education and the concept of the country in democratic education are very similar. A teacher who does not take into account the interests and needs of his students is like a governor who does not see the wishes of his people in a democratic country. Conversely, a classroom model that learns together is like the person ruling the country with its nation.

Within these structures, democratic education is a type of education that considers needs, responds to them, and produces solutions. In this context, of course, educational problems will also be encountered. The solution will again be sought in the public as required and imposed by democracy. In this respect, education should serve the individual, not the individual to education. Democratic education should determine the needs of individuals and society. Both must be in communication and interaction with each other.

Democratic education has many social, political, economic, and individual functions (Starkey, 2005). Raising self-actualized individuals will allow for the perfect performance of all of these functions. At this stage, solution processes should be given, and field experts should find answers to the problems. Otherwise, in societies where democratic education is not given, individual confidence declines, and the process of reaching a solution may take longer. Successful outcomes can be obtained if the individual is respected and made to feel valuable. Even if challenges occur along the path to success, the person who understands his value will support democratic education in all forms of solutions.

In short, democratic education should be expressed in areas of practice rather than abstract thinking. There can be many models of democratic education. Rather than producing models, the models should be presented according to the needs of individuals and society. When all of these phases are considered, an effective and viable training program can be created.

\section{Culture of Coexistence}

Today, global problems are mostly caused by differences. Differences in races, religions, lifestyles, cultures, social and political status, education, and trends are the basis for all these experiences. So, what is the point of increasing the intensity of the conflicts resulting from these differences every day? In today's world, where physical conditions and space are no longer obstacles in interpersonal relations, the necessity for coexistence is obvious, but differences between people in various parts of the world continue to be grounds for conflict (Todorov, 2010). Today, a great need exists to understand the differences of people, societies, and cultures as the 
richness and learn the art of living together to make the world, which is under threat more than ever, suitable for human life and ensure universal peace. This will be possible with an education that is conscious and planned and perhaps based on intergenerational communication, oriented towards this goal.

Why do the differences that also form the basis of the clash of civilizations turn into conflict when in fact is the most naturally developing basic reality and color of life?

"The entire history of humanity, from the most primitive communities to the present day, shows that, unlike other living things, human beings do not have a uniform structure. In addition to the 'natural' features of this 'non-uniformity, such as age, gender, body structure, intelligence level, etc., it also has 'social' qualities wealth, education, reputation, lineage, etc." (Arslantürk \& Amman, 2009) Regardless of their level of education, every individual is aware that there is only one planet that can be lived on. For now, this is an absolute biological reality. Again, every individual knows that it is impossible for all people to be the same in everything, believe in the same thing, live and share the same culture, and enjoy the same things. This is a sociological reality.

So why do differences turn into conflicts, despite these two absolute realities? What are the ways to rehabilitate the attitude of marginalization without reaching dangerous levels? The social studies courses have many responsibilities here.

Integration is the art of being able to work with people's differences, both individually and with institutional structures such as associations, foundations, parties, and think tanks, and at least to meet common denominators. For this, it is essential to have common feelings. It is necessary to suppress the sense of marginalization, abandon approaches such as labeling, grouping, experience, and maintain virtues such as empathy, sacrifice, sharing, and tolerance. This is undoubtedly possible with a comprehensive education on values. The most important feature of these values is that they are the common denominator of every thought and belief group. This is a crucial point that gives humankind hope.

Communication, which is one of the inevitable elements of coexistence, is an indispensable element of social life, with or without differences between individuals, and the history of communication is thought to be as old as human history. In today's world, where communication opportunities and effectiveness are very good, there are opportunities to consider differences as social wealth without turning them into conflicts. In particular, "the impossibility of returning societies around the world to a completely isolated and unaffected model" (Berkay, 2002, p. 56) brings us closer to the fact that we have to learn to live together.

Modern societies and enlightened individuals should not impose their differences on the other but be aware of the differences, accept it as it is, and express itself by communicating based on common values that can be reconciled. In such an atmosphere, it may be easier to show their wealth to the other side, as well as the opportunity to contribute more to the establishment of a universal peaceful and tranquil environment (Savage \& Armstrong, 2007).

\section{Discussion and Conclusion}

This paper analyzed citizenship and human rights education within the scope of values education. In addition to citizenship rights and obligations, subjects such as human rights in general and values to be offered in the social studies curriculum are discussed in the paper. Four main values that can be offered within the citizenship and human rights framework in the social studies course are discussed in this study.

Feeling valuable, equality, democratic education, and a culture of coexistence are the values that should be given as a part of values education in school environments. Studies have discussed 
the importance of having the sense of being valuable (Yigit, 2018), providing democratic education to all individuals regardless of their identities, beliefs, or nationalities (Rothstein \& Jacobsen, 2006), respecting others' values and rights respected (Pieper \& Thomson, 2014), and treating individuals equally to make positive impacts on them (Cin, 2017). Analyzing the result of this study and those mentioned above together, in education environments, treating individuals to help them feel valuable and important should be an important aspect of education.

Equality, democratic education, and the culture of coexistence are the values that should not be ignored, in especially primary schools where students have the chance of understanding and internalizing the importance of those values. This study reveals that considering the needs of students of those ages is important in creating a democratic society. This finding is in line with the literature (Patel, 2018), stating that taking the interests and needs of students into account is key for democratic education.

The social studies course is closely related to social issues. To see these lessons as separate from society's reality and teach them while ignoring the needs of society means that the lessons are no longer in their proper place. Therefore, giving the basic values that have been briefly touched on above to raise active and effective citizens in the social studies course will mean having a healthier social structure in the future. The upbringing of generations who know their responsibility as citizens, who are aware of where their rights begin and end, will provide us with inner peace and offer societies the opportunity to compete with so-called socially and economically strong societies globally. Otherwise, it will be inevitable that people will be a passive, even other-driven society that is introverted, unable to face their problems or solve these problems, and therefore cannot compete with global powers. This situation is not specific to a nation but valid for all countries and people around the world.

Research shows that there are age and gender differences in human values (Vilar et al., 2020). It states that women were often higher in social and central purposes and men had higher personal objectives. This should tell the policymakers and educational authorities that values and priorities differ even among the same groups. Treating individuals in this way and accepting the differences as personal characteristics will help policies to reach their goals in creating the consciousness equality and justice in societies embracing different cultures.

\section{References}

Abdi, A. A., \& Carr, P. R. (2013). Educating for democratic consciousness. Peter Lang.

Amin, S., \& Ahmad, N. (2018). Ethnic diversity, social exclusion and economic determinants of crimes: A case study of Pakistan. Social Indicators Research, 140(1), 267-286.

Arslan, S., \& Yigit, M. F. (2016). Investigation of the impact of emotional intelligence efficacy on teachers' multicultural attitudes. Journal of Education \& Practice, 7(11), 147-157.

Arslantürk, Z., \& Amman, M. T. (2009). Sosyoloji/kavramlar-kurumlar-süreçler-teoriler (6th Bask1.) [Sociology/concepts-institutions-processes-theories (6th ed.)]. Çamlıca Yayınları.

Bailey, R. (2000). Teaching values and citizenship across the curriculum. Kagan Page Limited.

Banban, D. (2018). Harmony in diversity: An empirical study of harmonious co-existence in the multi-ethnic culture of Qinghai. International Journal of Anthropology \& Ethnology, 2, Article 1. https://doi.org/10.1186/s41257-018-0010-6

Berkay, F. (2002). Bir bütünleşme ve uzlaşma aracı olarak sosyal empati ile üç tabanlı sosyolojik yaklaşım [As a tool of integration and reconciliation social empathy and a three-way sociological approach]. In Dünyada ve Türkiye’de farklılaşma-çatışma bütünleşme-II. III. Ulusal Sosyoloji Kongresi (pp. 56-63). Sosyoloji Derneği Yayınları, 
Cin, F. M. (2017). Gender justice, education and equality: Creating capabilities for girls' and women's development. Palgrave Macmillan.

Clark, L., \& Hooser, A. (2018). Social studies in the elementary classroom: Helping students make sense of their world. Journal of Practitioner Research, 3(1), Article 3. https://doi.org/10.5038/2379-9951.3.1.1069

Dahl, R. A. (2021, March 9). Democracy. Encyclopedia Britannica. https://www.britannica.com/topic/democracy

Donaldson, T. (2016). Values in tension: Ethics away from home. Routledge.

Ergün, M. (1993). İnsan ve eğitimi-Mevlana üzerine bir deneme: Mevlana'nın eğitim görüşleri [An essay on man and his education - Rumi: Mevlana's views on education]. Ocak Yayınları.

Fine-Davis, M., \& Faas, D. (2014). Equality and diversity in the classroom: A comparison of students' and teachers' attitudes in six European countries. Social Indicators Research, 119(3), 1319-1334. https://doi.org/10.1007/s11205-013-0547-9

Gökçe, E. (2002). İlköğretim öğrencilerinin görüşlerine göre öğretmenlerin etkililiği [Teachers' effectiveness according to primary school students' views]. Ankara Üniversitesi Ĕgitim bilimleri Fakültesi Dergisi, 35(1-2), 1320-1338.

Jones, P. (2018). International human rights: Philosophical or political? [E-book]. In C. Simon, D. George, \& P. Jones (Eds.), National Rights, International Obligations (pp. 183-205). Taylor \& Francis.

Martorella, P. H. (1997). Social Studies for Elementary School Children: Developing Young Citizens (Subsequent ed.). Prentice Hall.

Ogurlu, U., \& Avincan, K. (2020). Right to education: Challenges and issues under the justice and development party era. In H. Aydin \& W. Langley (Eds.), Human rights in Turkey: Assaults on Human Dignity (1st ed., pp. 190-204). New York, NY: Springer. https://doi.org/10.1007/978-3-030-57476-5_14

Owen, D. (2018). On the right to have nationality rights: Statelessness, citizenship and human rights. Netherlands International Law Review, 65(3), 299-317. https://doi.org/10.1007/s40802-018-0116-7

Patel, D. J. (2018). Role of teachers in nation building. International Journal of Trend in Scientific Research \& Development, 2(5), 2086-2089. https://doi.org/10.31142/ijtsrd18247

Pieper, I. J., \& Thomson, C. J. H. (2014). The value of respect in human research ethics: A conceptual analysis and a practical guide. Monash Bioethics Review, 32(3-4), 232-253. https://doi.org/10.1007/s40592-014-0016-5

Rothstein, R., \& Jacobsen, R. (2006). The goals of education. Phi Delta Kappan, 88(4), 264-272. https://doi.org/10.1177/003172170608800405

Salter, P. S., Adams, G., \& Perez, M. J. (2017). Racism in the structure of everyday worlds: A cultural-psychological perspective. Current Directions in Psychological Science, 27(3), 150-155. https://doi.org/10.1177/0963721417724239

Sant, E. (2019). Democratic education: A theoretical review (2006-2017). Review of Educational Research, 89(5), 655-696. https://doi.org/10.3102/0034654319862493

Savage, T., \& Armstrong, D. G. (2007). Effective teaching in elementary social studies (6th ed.). Pearson.

Starkey, H. (2005). Democratic education and learning. British Journal of Sociology of Education, 26(2), 299-308. https://doi.org/10.1080/0142569052000329200

Steele, N. A. (2010). Three characteristics of effective teachers. Update: Applications of Research in Music Education, 28(2), 71-78. https://doi.org/10.1177/8755123310361769 
Todorov, T. (2010). The coexistence of cultures. Policy Futures in Education, 8(3-4), 419-426. https://doi.org/10.2304/pfie.2010.8.3.419

Tonbuloglu, B., Aslan, D., \& Aydin, H. (2016). Teachers' awareness of multicultural education and diversity in school settings. Eurasian Journal of Educational Research, 16(64), 1-28. https://doi.org/10.14689/ejer.64.1

Tyree, C.L. (1997). Teaching values to promote a more caring world: A moral dilemma for the 21 st Century. Journal for a Just and Caring Education, 3.

United Nations. (1948). Universal Declaration of Human Rights. https://www.un.org/en/aboutus/universal-declaration-of-human-rights

Vilar, R., Liu, J. H. F., \& Gouveia, V. V. (2020). Age and gender differences in human values: A 20-nation study. Psychology \& aging, 35(3), 345.

Yigit, M. F. (2017). Value priorities of public and private university students. Research in Social Sciences \& Technology, 2(1). https://doi.org/10.46303/ressat.02.01.1

Yigit, M. F. (2018). Does higher education change value perceptions? Journal of Culture \& Values in Education, 1(1), 1-8. https://doi.org/10.46303/jcve.01.01.1

Yigit, M. F., \& Kesmeci, M. (2015). Vatandaslik ve demokrasi egitiminde masal kullanimi [Use of fairy tales in citizenship and democracy education]. International Journal of Turkish Literature Culture Education, 4(4/3), 1320. https://doi.org/10.7884/teke.505

\section{Notes on Contributor}

Dr. Mehmet Fatih Yigit has studied Educational Leadership at the University of Cincinnati and Educational Theory and Policy at the Pennsylvania State University. He is currently an independent researcher. He previously served as a faculty member in Department of Sociology and head of Distance Education program. He frequently participates in conferences worldwide. Has published book chapters and articles in various peer-reviewed journals. He is the managing editor of the Journal of Culture and Values in Education. In the last few years, he focused on multiculturalism and values education in terms of citizenship especially in developing countries. 